\title{
SPROUTING USING SALINE WATER ON CHEMICAL COMPOSITION, ANTINUTRITIONAL COMPOUNDS AND AMINO ACID PROFILE OF CHICKPEA AND LENTIL SEEDS
}

\author{
Abd El-Azim ${ }^{1}$ M.A., Nashwa A.I. Abo El-Azam ${ }^{2}$, Afaf O. Serage ${ }^{1}$ \\ and Abdallah ${ }^{2}$ M.M.F. \\ 1- Regional Central for Food and Feed Agric. Res. Center. Giza, Egypt \\ 2- Horticulture Dept., Fac. of Agric., Ain Shams Univ., P.O Box 68, Hadayek Shubra 11241, \\ Cairo, Egypt \\ *Corresponding author: youmamdouh@yahoo.com
}

Accepted 5 June, 2018

\section{ABSTRACT}

Lentil and Chickpea seeds were used to investigated the effect of seed sprouting using tap and saline water on sprout growth, proximate analysis, energy, minerals content, anti-nutritional compounds and amino acid profile of sprouted samples comparing with dry seeds. Result revealed that higher $\mathrm{NaCl}$ concentration > 2000 ppm reduce sprouts radical length of both lentil and chickpea. Sterilized seeds sprouting using tap water and non-sterilized seeds sprouting using saline water decreased sprout moisture content and carbohydrate which resulting in reducing faecal and total coliform counts for both lentil and chickpea. Moreover these treatment increased protein content and energy, (Kcal /g) as compared with dry seeds and other treatments. Sprouting decreased antinutritional compounds compared with dry seeds with sharbly decreament in phytic acid followed by taninins content. Mineral content in sprouts were recorded. The chickpea sprout sample using steralized seeds with tap water for sprouting serve as good sources calcium and phosphorous. Amino acid profile of lentil and chickpea sprouts were also studied. Sprouts using saline water recorded higher lysine amino acid value compared with dry seeds while non-steralized chickpea seeds sprouts using saline water recorded the higher total sulpher amino acid (Methionen + Cystiean) value. Based on these results, sprouting process is recommended to increase nutritive value and decreased antinutritional compounds of lentil and chickpea seeds.
Keywords: Amino acide, Salinty, Chickpea, Lentil, Sprouting, Proximate analysis

\section{INTRODUCTION}

Legumes are the most traditional form of protein intake in the regular diet of the individuals. It's "poor man's meat " are rich sources of protein, calories, minerals and vitamins (Deshpande, 1992 and Iqbal et al 2006) Different Legumes are widely cultivated worldwide especially in the Afro Asian countries and among them, Lentil (Lens culinaris $m$ ) and Chickpea (Cicer arietinum L.) are the most important species (Shehata, 1992; Jukantial et al 2012 and lqbal et al 2006).

Lentil plants are grown for their small lens shaped edible seeds, which are rich in protein (35$40 \%$ ) and carbohydrates, and are good sources of calcium, phosphorus, iron and B vitamins (Giannakoula et al 2012). Lentil is also high in lysine and therefore a great complement to the amino acid content of cereal grains (Forzana and Khalil, 1999).

Chickpea, seeds are usually comsumed in Egypt as whole or decorticated after cooking and processing in different ways and also the flour of decorticated seeds is used as supplement in bread and biscuits (Alajaji and El-Adawy, 2006). Chickpea is a good source of carbohydrates and protein. Morever protein quality is considered to be better than other legumes. It has significant amounts of all the essential amino acid except sulphur- containing amino acids (Jukantia et al 2012). On the other hand, legumes in particular lentil and chick- 
pea seeds have been reported to contain adequate amounts of antinutrients (Alonso et al 2000). Biological utitization of existing nutrients of these legumes is limited by the presence of various antinutritional substances (Lienes, 1994). The mineral content of legumes is generally high, but the bio avilibilityis poor due to the presence of phytate, which is a main inhibitor of iron and zinc absorption (Sanberg, 2002). Phytate not only decreases the bio - availability of essential minerals, it also decreases the bio- availability of proteins by forming in soluble phytate - mineral and phytate - protein complexes (Cheryan, 1980 and Reddy \& SalunKhe, 1981). Most of The toxic and antinutrent effcts of these compounds could be removed by several processing methods such as soakin, germination and sprouting (Soetan, 2008 and Kalpanadevi and Mohan, 2013; Mahmoud and El-Anany 2014 and Ibrahem 2017).

Sprouting and production of sprouts are an old habit that was adopted of thousands of year's age by the ancient Egyptians (Abdallah, 2008). Sprouting is the pratice of soaking and leaving seeds until they germinate and begin to sprout. This practice is reported to be associated with improvements in the nutritive value of seeds (Khattak et al 2007 and Kumar et al 2010). Salinity is one of the most serious a biotic stress that affects, crop production in the arid and semi - arid zone of the world. Seed germination and seedling growth are known to be more sensitive to salt stress compared with later development stages (Ashraf 1994 and Yildirim et al 2002). Salt stress negatively affects plant morphology and physiology through osmotic and ionic stress changes biochemical responses in plant (Khan et al 2013). On The other hand, salt stress stimulates the activity of antioxidant system (Rady. 2011 and Semida \& Raoly, 2014).

The aim of the present study was to investigate the effects of sprouting using saline water on sprout characters chemical composition and antinutritional compounds of Lentil and Chickpea.

\section{MATERIALS AND METHOD}

The present study was carried out in Horticulture Department, Faculty of Agriculture, Ain Shams University and the Regional Center for Food and Feed (RCFF), Agriculture Research center $(A R C)$.

\section{Seeds and Sprouting methods}

Seeds of Chickpea (Giza 531 cv.) and Lentil (Giza $9 \mathrm{cv}$.) were obtained from Agriculture Research Center, Giza. $\mathrm{NaCl}$ was obtained from ElGomhoria, a chemical company, Cairo. Sprouting of seeds was done in glass jar method as reported by Abdallah (2008), using tap water and $\mathrm{NaCl}$ at 1000, 2000, 3000, 4000 ppm solution for seed soaking and sprouting. Chickpea sprouts harvested one day from seed soaking while Lentil sprouts harvested two days from soaking. Seeds and harvested sprouts dried using air draft oven at $65{ }^{5} \mathrm{C}$ then grounded into powder for chemical analysis. At sprout harvest time also samples of sprouts were collected for measuring sprout characters (radical length $(\mathrm{cm})$ and 10 sprouts fresh and dry weight (mg)

\section{Chemical composition investigation}

All chemical composition analysis was carried out in the Regional Center for Food and Feed (RCFF), Agriculture Research center (ARC).

\section{Proximate analysis}

Crude protein, fat, ash and crud fiber contents of samples were determined according to AOAC. (2012). Total carbohydrates were determined by subtracting. Energy value was calculated using the Atwater factor method ( $9^{*}$ fat $)+\left(4^{*}\right.$ carbohydrate $)+$ (4*protein) as described by Osborne and Voogt (1978); Eneche (1991); Chinma and Igyor (2007) and Nwabueze (2007).

\section{Total Coliform and feacal coliform counts}

Were determined on MacConkey agar using pouring plate technique. Suitable plates were counted after 24 hours incubation at $37^{\circ} \mathrm{C}$ and $44.5^{\circ} \mathrm{C}$ for total Coliform and feacal Coliform counts Shalaby et al (2017).

\section{Amino acid profile and nutritional quality}

Amino acids determination was performed according to AOAC (2012). The system used for the analysis was Eppendorf LC 3000.EZ.chrom. 
Sprouting using saline water on chemical composition, antinutritional compounds and amino acid profile of chickpea and lentil seeds

\section{Estimation of nutritional quality of sprouts}

Nutritional quality of the sprouts samples were determined as the amino acid profiles .the essential amino acid index (EAAl) was calculated using the method of Labuda et al (1982) cited by ljarotimi and Keshinro (2013) according to following equation:

EAAI $=$

$\frac{8 \sqrt{(\text { Lys } * \text { Thero } * \text { Val } * \text { Meth } * \text { Lsoleu } * \text { Leu } * \text { Phynlal } * \text { Histi }) a}}{(\text { Lys } * \text { Thero } * \text { Val } * \text { Meth } * \text { Lsoleu } * \text { Leu } * \text { Phynlal } * \text { Histi }) b}$

Where : (lysine, isoleucine, valine, threonine, leucine, phenylalanine, histidine and methionine ) a in test sample and (lysine, isoleucine, valine, threonine, leucine, phenylalanine, histidine and methionine) $b$ content of the same amino acids in casein sa standard protein (\%) Aly, Tahany et al (2018). The nutritional index of the food samples was calculated using the formula below :

Nutritional index (\%) $=\frac{E A A I * \% \text { protein }}{100}$

The biological value was calculated according to Oser, (1959) cited by Mune - Mune et al (2011) using the following equation:

$$
B V=1.09 * E A A I-11.7
$$

The protein Efficiency Ratio (PER) was estimated according to the regression equations developed by Alsmeyer et al (1974). Cited by Abdallah and El-Ghandour, (2017) as given below :

$$
P E R=-0.468+0.454(\text { LEU) }-0.105(\text { TYR })
$$

\section{Calculation of other protein quality parameters}

Determination of the ratio of total essential amino acids (TEAA) to the total amino acids (TAA), i.e. (TEAA / TAA), total sulphur amino acids (TSAA), percentage cysteine in TSAA (\%Cys/ TSAA), total aromatic amino acids (TArAA), total acidic amino acids (TAAA) and total basic amino acids (TBA A) were estimated from the results obtained for amino acids profiles .

\section{Anti nutrients Analysis}

\section{Total oxalate}

Total oxalates were determined through titration methods according to Day and Underwood (1986).
Phytic acid

Phytic acid was determined based on precipitation of phytate according to the procedure of Wheeler and Ferrel (1971)

\section{Total tannins}

Total tannins were determined by spectrophotometric mehod as described by Makkareta I. (1993).

\section{Alkaloids assay}

The determination of alkaloids was done by the procedure proposed by Harbone (1973) and further explained by Onwuka (2006).

\section{Minerals determination}

Phosphorus (P) .magnesium (Mg) and potassium $(\mathrm{K})$ were analyzed by atomic absorption spectrophetometry 3300 Perken Elmer while calcium (Ca) was analyzed by ICP optima 2000 DV Perken Elmer according to the method described in the AOAC (2012).

\section{Statistical analysis}

The sprout characters data were statistically analyzed by analysis of variance using completely randomized design and least significant difference (L.S.D) at 0.05 levels according to the method described by Snedecor and Cochran (1980).

\section{RESULTS AND DISCUSSION}

1- Effect of sprouting using saline water on growth characters and chemical composition of Chickpea and Lentil sprouts

\section{1-1- Effect on sprout characters}

Data in Table (1) showed no significant difference between tap water and 1000 and 2000 ppm $\mathrm{NaCl}$ in Chickpea and Lentil radical length, and sprout Fresh and dry weight. The longest radical length was observed in $2000 \mathrm{ppm} \mathrm{NaCl}$ while the shortest length was observed in 4000 ppm NaCl. However sterilized Chickpea seed decreased sprout radical length but increased sprout Fresh and dry weight, while sterilized Lentil seeds not affected sprout characters (Table 1). Moreover, sprouts radical length and Fresh and dry weight of 
sterilized and non-sterilized seeds for both crops showed - higher data in 2000 ppm NaCl with no significant differences compared with control (tap water). Therefore $2000 \mathrm{ppm} \mathrm{NaCl}$ was selected for the following studies. Similar results on the reduction effect of sprout radical length with higher $\mathrm{NaCl}$ concentration were reported by Ghoulam and Fares (2001) and Ibrahim (2017).

\section{1-2- Effect on proximate composition of sprout flour}

Moisture content of Chickpea and Lentil sprout flour were the lowest with sterilized seeds sprouting using tap water ( $8.2 \%$ and $9.6 \%$ respectively) and with non-sterilized seeds sprouting using saline water ( $9.5 \%$ and $8.2 \%$ respectively). A previous investigation showed that low moisture content in food samples increased the storage periods (Alozie et al 2009), since the microbial activity is reduced (Oyenuga, 1968). However data of total and Faecal coliform count in Table (2) agree with these phenomena (The microbial activity reduced when moisture content decreased). Carbohydrate content in Chickpea and Lentil sprout flour showed similar decreases for moisture content in the same treatments samples which showed that sterilized seeds sprouting using tap water $54.98 \%$ and $50.62 \%$ respectively for both crops and nonsterilized seeds sprouting using saline water, $53.68 \%$ and $49.69 \%$ respectively for both crops.

On the other hand, protein recorded higher content in both crop with lower moisture content for all treatments. Protein content in Chickpea and Lentil sprout flour recorded $22.6 \%$ and $30.7 \%$ respectively with sterilized seeds sprouting using tap water and recorded $22.4 \%$ and $31.8 \%$ respectively with non-sterilized seeds sprouting using saline water (Table 2). However flour of Lentil sprouts showed higher protein content than Chickpea sprout flour.

Also the protein content of sprouted crop flour was higher than that of whole dry seeds flour. This observation was greed with other scientific findings that sprouting improved protein content (Abdallah, 2008, Fasasi 2009 and Ibrahim 2017). Moreover

Table 1. Effect of $\mathrm{NaCl}$ concentrations in sprouting solution on one day old Chickpea and 2 day old Lentil sprout characters

\begin{tabular}{|c|c|c|c|c|c|c|c|}
\hline \multirow[b]{2}{*}{ Steralization } & \multirow{2}{*}{$\begin{array}{c}\text { Crop } \\
\begin{array}{c}\mathrm{Na} \mathrm{Cl} \\
\text { Concentration } \\
\text { ppm }\end{array}\end{array}$} & \multicolumn{3}{|c|}{ Chickpea } & \multicolumn{3}{|c|}{ Lentil } \\
\hline & & $\begin{array}{c}10 \\
\text { Radical } \\
\text { length } \\
(\mathrm{cm})\end{array}$ & $\begin{array}{c}10 \\
\text { Sprout } \\
\text { fresh } \\
\text { weight } \\
\text { (mg) }\end{array}$ & $\begin{array}{c}10 \\
\text { Sprout } \\
\text { Dry } \\
\text { weight } \\
\text { (mg) }\end{array}$ & $\begin{array}{c}10 \\
\text { Radical } \\
\text { length } \\
(\mathrm{cm})\end{array}$ & $\begin{array}{c}10 \\
\text { Sprout } \\
\text { fresh } \\
\text { weight } \\
\text { (mg) }\end{array}$ & $\begin{array}{c}10 \\
\text { Sprout } \\
\text { Dry } \\
\text { weight } \\
\text { (mg) }\end{array}$ \\
\hline $\begin{array}{l}\text { Sterilized } \\
\text { seeds }\end{array}$ & $\begin{array}{c}\text { Tap water }^{(1)} \\
1000 \\
2000 \\
3000 \\
4000 \\
\text { Mean } \\
\end{array}$ & $\begin{array}{l}0.42 \mathrm{~cd} \\
0.44 \mathrm{~cd} \\
0.45 \mathrm{~cd} \\
0.40 \mathrm{~cd} \\
0.28 \mathrm{~d} \\
\mathbf{0 . 4 0 ~ B}\end{array}$ & $\begin{array}{c}486 a \\
475 a \\
488 a \\
449 a b \\
446 a b \\
465 A \\
\end{array}$ & $\begin{array}{c}185 a b \\
188 a b \\
191 a \\
171 \mathrm{bc} \\
179 a b \\
183 \mathbf{A} \\
\end{array}$ & $\begin{array}{c}1.31 \mathrm{abc} \\
1.43 \mathrm{ab} \\
1.48 \mathrm{a} \\
1.14 \mathrm{cde} \\
0.89 \mathrm{e} \\
\mathbf{1 . 2 5 ~ A} \\
\end{array}$ & $\begin{array}{c}78 a b c \\
79 a b c \\
83 a \\
72 c \\
73 \mathrm{bc} \\
77 \mathrm{~A} \\
\end{array}$ & $\begin{array}{l}24 \mathrm{a} \\
25 \mathrm{a} \\
26 \mathrm{a} \\
25 \mathrm{a} \\
23 \mathrm{a} \\
25 \mathrm{~A}\end{array}$ \\
\hline $\begin{array}{l}\text { Non-Sterilized } \\
\text { seeds }\end{array}$ & $\begin{array}{l}\text { Tap water } \\
1000 \\
2000 \\
3000 \\
4000 \\
\text { Mean }\end{array}$ & $\begin{array}{l}1.02 \mathrm{a} \\
1.14 \mathrm{a} \\
1.17 \mathrm{a} \\
0.78 \mathrm{~b} \\
0.55 \mathrm{C} \\
\mathbf{0 . 9 3} \mathrm{A}\end{array}$ & $\begin{array}{l}402 b \\
449 a b \\
450 a b \\
446 a b \\
395 b \\
429 \text { B }\end{array}$ & $\begin{array}{l}171 \mathrm{bc} \\
179 a b \\
180 a b \\
158 \mathrm{c} \\
157 \mathrm{c} \\
169 \mathrm{~B}\end{array}$ & $\begin{array}{l}1.11 \mathrm{cde} \\
1.17 \mathrm{bcde} \\
1.27 \mathrm{abcd} \\
1.12 \mathrm{cde} \\
1.03 \mathrm{de} \\
\mathbf{1 . 1 4} \mathbf{A}\end{array}$ & $\begin{array}{l}72 \mathrm{c} \\
75 \mathrm{bc} \\
78 \mathrm{abc} \\
76 \mathrm{bc} \\
79 \mathrm{ab} \\
76 \mathrm{~A}\end{array}$ & $\begin{array}{l}22 \mathrm{a} \\
26 \mathrm{a} \\
26 \mathrm{a} \\
25 \mathrm{a} \\
25 \mathrm{a} \\
26 \mathrm{~A}\end{array}$ \\
\hline Average & $\begin{array}{l}\text { Tap water } \\
1000 \\
2000 \\
3000 \\
4000 \\
\end{array}$ & $\begin{array}{l}0.72 \mathrm{AB} \\
0.79 \mathrm{~A} \\
0.81 \mathrm{~A} \\
0.59 \mathrm{~B} \\
0.42 \mathrm{C}\end{array}$ & $\begin{array}{c}444 \mathrm{AB} \\
462 \mathrm{AB} \\
469 \mathrm{~A} \\
447 \mathrm{AB} \\
421 \mathrm{~B}\end{array}$ & $\begin{array}{l}178 \mathrm{AB} \\
183 \mathrm{~A} \\
185 \mathrm{~A} \\
164 \mathrm{C} \\
168 \mathrm{AB}\end{array}$ & $\begin{array}{c}1.21 \mathrm{AB} \\
1.30 \mathrm{AB} \\
1.37 \mathrm{~A} \\
1.13 \mathrm{BC} \\
0.96 \mathrm{C}\end{array}$ & $\begin{array}{c}75 \mathrm{~B} \\
77 \mathrm{AB} \\
80 \mathrm{~A} \\
74 \mathrm{~B} \\
76 \mathrm{AB}\end{array}$ & $\begin{array}{l}25 A \\
26 A \\
26 A \\
25 A \\
24 A\end{array}$ \\
\hline LSD 0.05 & $\begin{array}{c}\text { Sterilization } \\
\text { (ST) } \\
\mathrm{NaCl} \text { conc. } \\
\mathrm{ST}^{\star} \mathrm{NaCl} \text { conc. }\end{array}$ & $\begin{array}{l}0.091 \\
0.143 \\
0.203 \\
\end{array}$ & $\begin{array}{l}27.6 \\
43.7 \\
61.8 \\
\end{array}$ & $\begin{array}{l}8.3 \\
13.1 \\
18.6 \\
\end{array}$ & $\begin{array}{l}\text { N.S } \\
\\
0.198 \\
0.279 \\
\end{array}$ & $\begin{array}{l}\text { N.S } \\
4.6 \\
6.5 \\
\end{array}$ & $\begin{array}{l}\text { N.S } \\
\text { N.S } \\
\text { N.S }\end{array}$ \\
\hline
\end{tabular}

Tap water $=$ control $^{(2)}$ N.S $=$ not Significant ${ }^{(1)}$ 
Sprouting using saline water on chemical composition, antinutritional compounds and amino acid profile of chickpea and lentil seeds

Moongngarm and Saetung (2010) reported that several enzymes were activated during germination process which produced some non-protein nitrogen substances, such as nucleic acid which can caused protein level to be increased. Regarding fat content data in Table (2) recorded increase in sprouts flour sample as compared with whole seed flour. Chickpea flour recorded more fat than Lentil flour. Total fiber and ash showed higher content in both crop flour samples and these results can discussed by containing fibrous materials in the form of seed coat which can removed in the sivied flour. Energy values of both crop sprout flour samples were higher than those of raw seed flour samples (Table 2). The higher energy values recorded in the lowest moisture content and higher protein content (sterilized seeds sprouting using tap water and non - sterilized seed sprouting using saline water treatments in both crops).

\section{1-3- Effect on anti- nutrient factor in Chickpea and Lentil Flour}

The antinutrient composition of whole seeds and sprouts flour of Chickpea and Lentil samples are presented in Table (3). The phytic acid decreased sharbly in sprout flour compared to whole seed flour. Data was more pronounced with lower moisture content flour treatment in both crops i.e. sterilized seed sprouting using tap water ( 0.03 and $0.09 \mathrm{mg}$ respectively) and non-sterilized seed sprouting using saline water $(0.03$ and 0.07 respectively). Tannins content showed similar results as phytic acid which recorded $0.44 \mathrm{mg}$ and 0.62 $\mathrm{mg}$ respectively in Chickpea and Lentil sterilized seed sprouting using tap water and $0.29 \mathrm{mg}$ and $0.71 \mathrm{mg}$ in both crops respectively in non - sterilized seed sprouting using saline water compared to $0.86 \mathrm{mg}$ in Chickpea and $1.33 \mathrm{mg}$ in Lentil

Table 2. Effect of sprouting using saline water ( $\mathrm{NaCl} 2000 \mathrm{ppm})$ on the proximate analysis and energy and microbial counts of one day Chickpea (chick) and 2 day Lentil (Lent) sprout flour (g/100 D.W)

\begin{tabular}{|c|c|c|c|c|c|c|c|c|c|}
\hline Nutrients (\%) & Moisture & Protein & $\begin{array}{c}\text { Carbohy } \\
\text { drate }\end{array}$ & Fat & Fiber & Ash & $\begin{array}{c}\text { Energy/ } \\
\text { kcal/g }\end{array}$ & $\begin{array}{c}\text { Total } \\
\text { Coliform } \\
\text { Count }\end{array}$ & $\begin{array}{l}\text { Faecal } \\
\text { Coliform } \\
\text { Count }\end{array}$ \\
\hline & \multicolumn{7}{|c|}{ Chickpea } & & \\
\hline Whole Seeds & 11.3 & 18.3 & 57.73 & 4.4 & 5.28 & 3.0 & 344 & $x^{-1}+5 s$ & - \\
\hline $\begin{array}{l}\text { Chick sprout- } \\
\mathrm{TW}^{(1)}-\mathrm{ST}^{(2)}\end{array}$ & 8.2 & 22.6 & 54.98 & 5.0 & 6.87 & 2.4 & 355 & $>10^{6} \mathrm{cfu} / \mathrm{g}$ & $>10^{6} \mathrm{cfu} / \mathrm{g}$ \\
\hline $\begin{array}{l}\text { Chick sprout- } \\
\text { TW -N ST }\end{array}$ & 11.8 & 18.3 & 58.26 & 4.9 & 4.82 & 2.0 & 350 & $\begin{array}{r}22 * 10^{7} \\
\mathrm{cfu} / \mathrm{q}\end{array}$ & $\begin{array}{c}60 * 10^{6} \\
\mathrm{cfu} / \mathrm{q}\end{array}$ \\
\hline $\begin{array}{l}\text { Chick sprout- } \\
S W^{(4)}-S T\end{array}$ & 10.8 & 18.3 & 59.97 & 4.3 & 4.76 & 1.9 & 352 & $\begin{array}{c}23 * 10^{7} \\
\mathrm{cfu} / \mathrm{g}\end{array}$ & $\begin{array}{c}26^{*} 10^{6} \\
\mathrm{cfu} / \mathrm{g}\end{array}$ \\
\hline \multirow{2}{*}{$\begin{array}{l}\text { Chick sprout- } \\
\text { SW -N ST }\end{array}$} & 9.5 & 22.4 & 53.68 & 5.3 & 6.39 & 2.7 & 352 & $>10^{6} \mathrm{cfu} / \mathrm{g}$. & $>10^{6} \mathrm{cfu} / \mathrm{g}$ \\
\hline & \multicolumn{7}{|c|}{ Lentil } & & \\
\hline Whole Seeds & 11.1 & 25.2 & 55.39 & 0.6 & 5.36 & 2.4 & 327 & - & - \\
\hline $\begin{array}{c}\text { Lent sprout- } \\
\text { TW - ST }\end{array}$ & 9.6 & 30.7 & 50.62 & 0.9 & 5.85 & 2.3 & 334 & $>10^{6} \mathrm{cfu} / \mathrm{g}$ & $>10^{6} \mathrm{cfu} / \mathrm{g}$ \\
\hline $\begin{array}{l}\text { Lent sprout- } \\
\text { TW -N ST }\end{array}$ & 9.8 & 25.3 & 55.28 & 1.1 & 6.33 & 2.2 & 332 & $\begin{array}{c}19^{*} 10^{7} \\
\mathrm{cfu} / \mathrm{g}\end{array}$ & $\begin{array}{c}89^{*} 10^{6} \\
\mathrm{cfu} / \mathrm{g}\end{array}$ \\
\hline $\begin{array}{l}\text { Lent sprout- } \\
\text { SW - ST }\end{array}$ & 11.7 & 24.8 & 53.49 & 1.0 & 6.76 & 2.3 & 322 & $\begin{array}{c}67^{*} 10^{7} \\
\mathrm{cfu} / \mathrm{g}\end{array}$ & $\begin{array}{c}45^{\star} 10^{7} \\
\mathrm{cfu} / \mathrm{g}\end{array}$ \\
\hline $\begin{array}{l}\text { Lent sprout- } \\
\text { SW -N ST }\end{array}$ & 8.2 & 31.8 & 49.69 & 1.0 & 6.81 & 2.5 & 335 & $>10^{6} \mathrm{cfu} / \mathrm{g}$ & $>10^{6} \mathrm{cfu} / \mathrm{g}$ \\
\hline
\end{tabular}

$\mathrm{TW}=$ tap water ${ }^{(2)} \mathrm{ST}=$ sterilized seeds ${ }^{(3)} \mathrm{NST}=$ non-sterilized seeds ${ }^{(4)} \mathrm{SW}=$ saline water ${ }^{(1)}$ 
whole seeds flour. Total oxalate ranged from 0.99 to $1.10 \mathrm{mg}$ in sprouted Chickpea less than whole seeds $(1.21 \mathrm{mg})$ and ranged from 0.99 to $1.21 \mathrm{mg}$ in Lentil sprouts less than whole seeds $(1.32 \mathrm{mg})$. Moreover, alkaloids ranged from $1.99 \mathrm{mg}$ to 4.21 $\mathrm{mg}$ in Chickpea sprouts and from $0.75 \mathrm{mg}$ to 2.52 $\mathrm{mg}$ in Lentil sprouts which ware lower than both crop whole seeds $(4.77 \mathrm{mg}$ and $2.56 \mathrm{mg}$ respectively). Table (3). The Alkaloids, oxalate, tannins and phytic composition of germinated Chickpea and Lentil flour sample were Lower from that of raw dry seeds flour samples. However, the values were compared to other reports (Mbithi- Mwikya et al 2001 and Ibrahim et al 2002). Scientific studies have established that germination improve the nutritional quality of food products by reducing or eliminating the anti - nutrient composition of the food products (Oboh et al 2000; Mbithi-Mwikya et al 2001; Ibrahim et al 2002 and Ibrahim 2017).

\section{1-4- Effect on mineral composition of sprout flour}

The mineral composition of Chickpea and Lentil sprout flour are shown in Table (4). The mineral composition showed that potassium $(\mathrm{K})$ had the highest value in the non-sterilized seed sprouting using tap water which recorded the highest $\mathrm{K}$ and $P$ values for both Chickpea (840 and $270 \mathrm{mg} / \mathrm{kg}$ ) and Lentil ( 870 and $390 \mathrm{mg} / \mathrm{kg}$ ) followed by sterilized seeds sprouting using saline water which amounted 660 and $260 \mathrm{mg} / \mathrm{kg}$ in Chickpea and 850 and $370 \mathrm{mg}$ in Lentil for both $\mathrm{K}$ and $\mathrm{P}$ values respectively. However the high intake of potassium has been reported to protect against increasing blood pressure and other cardiovascular risk (Lang Ford, 1983 and Cappuccio and McGregor, 1991).

Table 3. Effect of sprouting using saline water ( $\mathrm{NaCl} 2000 \mathrm{ppm}$ ) on anti-nutritional conpounds of one day Chickpea (chick) and 2 day Lentil (Lent) sprout flour (g/100 g D.W)

\begin{tabular}{|c|c|c|c|c|}
\hline anti-nutritional conpounds & Alkaloids & Totol oxalate & Total tannins & Phytic acid \\
\hline & \multicolumn{4}{|c|}{ Chickpea } \\
\hline Whole Seeds & 4.77 & 1.21 & 0.86 & 0.62 \\
\hline Chick sprout-TW(1) $-\mathrm{ST}^{(2)}$ & 3.02 & 1.10 & 0.44 & 0.03 \\
\hline Chick sprout-TW -N ST ${ }^{(3)}$ & 2.03 & 0.99 & 0.37 & 0.11 \\
\hline Chick sprout-SW ${ }^{(4)}-\mathrm{ST}$ & 1.99 & 0.99 & 0.30 & 0.06 \\
\hline \multirow[t]{2}{*}{ Chick sprout-SW -N ST } & 4.21 & 1.10 & 0.29 & 0.03 \\
\hline & \multicolumn{4}{|c|}{ Lentil } \\
\hline Whole Seeds & 2.56 & 1.32 & 1.33 & 0.86 \\
\hline Lent sprout-TW - ST & 2.43 & 1.21 & 0.62 & 0.09 \\
\hline Lent sprout-TW -N ST & 1.11 & 0.99 & 1.05 & 0.58 \\
\hline Lent sprout-SW - ST & 0.75 & 1.10 & 1.30 & 0.69 \\
\hline Lent sprout-SW -N ST & 2.52 & 0.99 & 0.71 & 0.07 \\
\hline
\end{tabular}

\footnotetext{
${ }^{(1)} \mathrm{TW}=$ tap water ${ }^{(2)} \mathrm{ST}=$ sterilized seeds ${ }^{(3)} \mathrm{NST}=$ non-sterilized seeds ${ }^{(4)} \mathrm{SW}=$ saline water
} 

compounds and amino acid profile of chickpea and lentil seeds

Table 4. Effect of sprouting using saline water $(\mathrm{NaCl} 2000 \mathrm{ppm})$ on minerals content of one day Chickpea (chick) and 2 day Lentil (Lent) sprout flour (mg/k g D.W)

\begin{tabular}{|c|c|c|c|c|}
\hline Minerals & Ca & P & Mg & K \\
\hline \multicolumn{4}{|c|}{ Chickpea } \\
\hline Chick sprout-TW $^{(\mathbf{1})}-\mathbf{S T}^{(\mathbf{2})}$ & 270 & 250 & 150 & 620 \\
Chick sprout-TW -N ST $^{(3)}$ & 120 & 270 & 130 & 840 \\
Chick sprout-SW $^{(\mathbf{4})}$ - ST & 180 & 260 & 90 & 660 \\
Chick sprout-SW -N ST $^{\mid} 110$ & 220 & 150 & 530 \\
\hline \multicolumn{4}{|c|}{ Lentil } \\
\hline Lent sprout-SW-ST - ST & 120 & 221 & 110 & 590 \\
Lent sprout-TW -N ST & 80 & 390 & 110 & 870 \\
Lent sprout-SW - ST & 120 & 370 & 95 & 850 \\
Lent sprout-SW -N ST & 67 & 280 & 110 & 430 \\
\hline
\end{tabular}

${ }^{(1)} \mathrm{TW}=$ tap water ${ }^{(2)} \mathrm{ST}=$ sterilized seeds ${ }^{(3)} \mathrm{NST}=$ non-sterilized seeds ${ }^{(4)} \mathrm{SW}=$ saline water

On the other hand, sprouting of non - sterilized seeds using tap water or saline water decreased calcium $(\mathrm{Ca})$ level for both Chickpea and Lentil compared with using Sterilized seeds in sprouting process. It was observed in this study that using non-sterilized seeds with tap water or sterilized seeds with saline water for sprouting Chickpea and lentil improved $\mathrm{K}$ and $\mathrm{P}$ composition of the flour samples except in magnesium (Mg). Nutritionally the ratio of $\mathrm{Ca} / \mathrm{P}$ of the flour samples range between 0.7 to 1.1 using sterilized Chickpea seeds for sprouting with saline water and tap water respectively and range between 0.3 to 0.5 for Lentil sterilized seeds sprouting with both saline water and tap water respectively. However lower $\mathrm{Ca} / \mathrm{P}$ values were obtained using non- sterilized seeds for sprouting Chickpea (0.5 to 0.44 ) and Lentil $(0.24$ and 0.21$)$ using both saline water and tap water for sprouting respectively. This finding indicated that Chickpea sprout flour sample using sterilized seeds and tap water for sprouting process serve as good sources calcium and phosphorous, which are considered essential for bone and teeth formation and development in children. However, it is evident that food products containing a $\mathrm{Ca} / \mathrm{P}$ ratio of $>1.0$ is rated good while $<0.5$ is rated poor (Nieman et al 1992).

\section{1-5- Effect on amino acid profile and nutritional quality of sprout flour}

The amino acid profile and nutritional quality of Chickpea and Lentil sprout flour samples are presented in Tables (5) and (6). Data in Table (6) showed that glutamic acid was found to be the most abundant in Chickpea whole seeds flour (16$17 \mathrm{~g} / 100 \mathrm{~g}$ ) and two sprouts flour (from non- sterilized seeds sprouting using saline water (16-25 g $/ 100 \mathrm{~g})$ sterilized seeds sprouting using tap water, $(16.06 \mathrm{~g} / 100 \mathrm{~g})$, followed by aspartic acid in the same whole seeds $(11.53 \mathrm{~g} / 100 \mathrm{~g}$ respectively) and both sprouts flour (10-22 and $10.08 \mathrm{~g} / 100 \mathrm{~g}$ respectively). Also glutamic acid followed by aspartic which recorded the higher composition in Lentil whole seeds flour (17.61 and $10.99 \mathrm{~g} / 100 \mathrm{~g}$ respectively) and in sprouts flour of sterilized seeds sprouting using saline water (17.82 and $10.84 \mathrm{~g}$ $1100 \mathrm{~g}$ respectively) (Table 5). On the other hand methionine was the least in both crop whole seeds and sprouts flour samples which ranged from 1.21 to $2.07 \mathrm{~g} / 100 \mathrm{~g}$ in Chickpea samples and from 0.81 to $1.0 \mathrm{~g} / 100 \mathrm{~g}$ in Lentil flour sample. The sprouting decreased the content of almost all the amino acids especially in tap water Chickpea and Lentil sprouts except proline in Chickpea and cystine in non- sterilized Lentil seeds as compared with whole seeds. Moreover. Lentil sprouting in saline water for both sterilized and non- sterilized seeds in addition to non-sterilized Chickpea sprouting in saline water also decreased the content of the amino acids as compared with whole Chickpea and Lentil seeds except proline and cystine in non-sterilized Chickpea sprouts. Opposite results were obtained in sterilized Lentil seeds sprouting in saline water. The sprouting increased the content of almost the amino acids in salted Lentil sprouts except therionin, aspartic acids, serine, proline and glycine. 
Table 5. Effect of sprouting using saline water ( $\mathrm{NaCl} 2000 \mathrm{ppm}$ ) on amino acids (AA) composition ( $\mathrm{g} / 100 \mathrm{~g}$ protein) of one day Chickpea (chick) and 2 days Lentil (lent) sprout flour

\begin{tabular}{|c|c|c|c|c|c|c|c|c|c|c|}
\hline $\begin{array}{l}\text { amino acids } \\
\text { (AA) } \\
\text { composition }\end{array}$ & $\begin{array}{l}\text { Whole } \\
\text { seeds }\end{array}$ & $\begin{array}{l}\text { Chick } \\
\text { TW }^{(1)} \\
-\mathrm{ST}^{(2)} \\
\end{array}$ & $\begin{array}{l}\text { Chick } \\
\text { TW - } \\
\text { NST }^{(3)}\end{array}$ & $\begin{array}{l}\text { Chick }^{(4)} \\
\text { SW }^{(4)} \\
\text { - ST }\end{array}$ & $\begin{array}{l}\text { Chick } \\
\text { SW - } \\
\text { NST }\end{array}$ & $\begin{array}{l}\text { Whole } \\
\text { seeds }\end{array}$ & $\begin{array}{c}\text { Lent } \\
\text { TW- } \\
\text { ST }\end{array}$ & $\begin{array}{l}\text { Lent } \\
\text { TW - } \\
\text { NST }\end{array}$ & $\begin{array}{l}\text { Lent } \\
\text { SW - } \\
\text { ST }\end{array}$ & $\begin{array}{c}\text { LentSW } \\
\text { - NST }\end{array}$ \\
\hline \multicolumn{11}{|l|}{ Essential AA } \\
\hline Isoleucine & 4.04 & 3.76 & 3.64 & 3.42 & 3.75 & 3.84 & 3.64 & 3.67 & 4.07 & 3.52 \\
\hline Valine & 5.73 & 4.07 & 3.69 & 3.78 & 4.06 & 1.26 & 5.08 & 4.54 & 5.12 & 5.09 \\
\hline Lysine & 7.04 & 6.37 & 5.72 & 5.67 & 6.38 & 7.26 & 6.18 & 6.75 & 7.50 & 6.06 \\
\hline Leucine & 7.26 & 6.76 & 6.66 & 6.30 & 6.60 & 7.10 & 6.38 & 6.48 & 7.13 & 6.13 \\
\hline Phenylalnin & 5.90 & 5.30 & 5.00 & 4.77 & 5.22 & 4.88 & 4.49 & 4.58 & 5.04 & 4.52 \\
\hline Therionin & 3.55 & 3.27 & 3.15 & 3.15 & 3.03 & 3.69 & 3.09 & 3.12 & 3.62 & 2.83 \\
\hline Methionin & 2.07 & 1.54 & 1.26 & 1.21 & 1.74 & 0.99 & 0.94 & 0.90 & 1.00 & 0.81 \\
\hline Histidin & 2.84 & 2.52 & 2.20 & 2.16 & 2.5 & 2.65 & 2.28 & 2.45 & 2.70 & 2.26 \\
\hline Total EAA & 38.43 & 33.59 & 31.32 & 30.46 & 33.28 & 31.67 & 32.08 & 32.49 & 36.18 & 31.22 \\
\hline \multicolumn{11}{|c|}{ Non- Essential AA } \\
\hline Alanine & 4.69 & 4.46 & 4.81 & 4.72 & 4.50 & 4.40 & 4.16 & 4.38 & 4.63 & 3.93 \\
\hline $\begin{array}{l}\text { Aspartic } \\
\text { acid }\end{array}$ & 11.53 & 10.08 & 9.63 & 9.50 & 10.22 & 10.99 & 9.60 & 10.19 & 10.84 & 9.15 \\
\hline Serine & 4.15 & 4.24 & 4.09 & 4.14 & 3.57 & 5.00 & 4.26 & 3.91 & 4.87 & 3.71 \\
\hline $\begin{array}{l}\text { Giutamic } \\
\text { acid }\end{array}$ & 16.17 & 16.06 & 14.77 & 14.36 & 16.25 & 17.61 & 15.40 & 15.84 & 17.82 & 15.15 \\
\hline Proline & 3.77 & 3.93 & 6.98 & 7.11 & 4.01 & 4.16 & 3.25 & 3.87 & 3.99 & 3.93 \\
\hline Giycine & 3.55 & 3.45 & 2.97 & 2.88 & 3.43 & 3.57 & 3.51 & 3.20 & 3.38 & 3.14 \\
\hline Cystine & 2.40 & 1.63 & 1.44 & 1.30 & 3.34 & 1.15 & 0.97 & 2.01 & 1.29 & 1.63 \\
\hline Tyrosine & 3.22 & 3.18 & 3.01 & 2.83 & 3.16 & 3.41 & 3.22 & 3.32 & 3.46 & 3.20 \\
\hline Arginine & 8.79 & 8.18 & 6.35 & 6.53 & 7.76 & 8.21 & 7.55 & 7.50 & 8.54 & 7.35 \\
\hline Totol NEAA & 58.27 & 55.21 & 54.05 & 53.37 & 56.24 & 58.5 & 51.92 & 54.22 & 58.82 & 51.19 \\
\hline Totol AA & 96.7 & 88.8 & 85.37 & 83.83 & 89.52 & 90.17 & 84.00 & 86.71 & 95.00 & 82.41 \\
\hline
\end{tabular}

${ }^{(1)} \mathrm{TW}=$ tap water ${ }^{(2)} \mathrm{ST}=$ sterilized seeds ${ }^{(3)} \mathrm{NST}=$ non-sterilized seeds ${ }^{(4)} \mathrm{SW}=$ saline water

The results of nutritional quality of Chickpea and Lentil seeds and their sprouts flour are presented in Table (6). Percentage of total essential amino acid including histidine and arginine recorded the highest values in all Lentil sprouts compared with Lentil whole dry seeds. Opposite results were obtained with Chickpea sprouts compared with Chickpea whole dry seeds. The percentage of total essential amino acid to total amino acid (TEAA / TAA \%) showed also that Lentil sprouts had the higher values than Lentil dry seeds but opposite results was obtained for Chickpea sprouts. On the other hand the percentage of total non- essential amino acid to total amino acid (TNEAA/TAA\%) showed the that Chickpea sprouts had the highest values (62.2 to $63.7 \%$ ) compared with Chickpea dry seeds value (60.3\%). In Lentil sprouts data showed that only sprouting non- sterilized seeds using tap water increased TNEAA/TAA\% (62.5\%) than dry Lentil seeds (62.3\%) and also decreased TEAA/ TNEAA\%
(59.9\%) than dry seeds (60.5\%). Moreover, all Chickpea sprouts decreased TEAA/ TNEAA values $(57.1 \%$ to $60.8 \%)$ than dry Chickpea seeds (66.0\%) (Table 6). Chickpea and Lentil grains and sprouts showed higher EAA/TAA\% ratio higher than $36.3 \%$. These values are above the value of $26 \%$ for ideal protein food for children and $11 \%$ for adult (FAO, WHO, UNU, 1985). Similar Chickpea data were obtained by Ibrahim (2017). The aromatic amino acid (ArAA), total acidic amino acid (TAAA) and basic amino acids (TBAA) showed lower values in Chickpea and Lentil sprouts compared with dry seeds except Lentil sprouts using sterilized seeds germinated in saline water (Table, 6). Total sulphur amino acids (TSAA) values were decreased in Chickpea sprouts except sprouts from non - sterilized seeds germinated in saline water, while the values in Lentil sprouts except sprouts germinated in tap water using sterilized seeds as compared with dry seeds of both Chickpea and Lentil. 

compounds and amino acid profile of chickpea and lentil seeds

These results were regarded to the value of Cystine amino acid as shown in CYS/ TSAA \% ratio in Table (6). Cystine is not an essential amino acid but can be synthesized from methionine, thus Cystine in a diet can be "spare" methionine. The values of protein efficiency ratio (PER) of Chickpea and Lentil seeds and their sprouts flour samples were between 2.0 in non- sterilized Lentil seeds sprouts using saline water to 2.5 in chickpea dry seeds flour (Table 6). In general Chickpea flour PER recorded the highest levels in seeds and tap water sprouts flour than the same Lentil flour - in addition to non- sterilized seed sprouts using saline water Round. Opposite results in sterilized seeds sprouting in saline water which recorded higher PER in Lentil (2.4) than similar in Chickpea (2.2) (Table 6). These increment in Lentil can explained by the increment in leucine and tyrosine amino acid composition (Table 5). However, the PER in both Chickpea and Lentil seeds and their sprouts flour were lower than 2.88 which was recorded in whole hen's egg (Paul et al 1976) and 2.5 that found in reference casein (Oyarekua and Eleyinmi, 2004), but they were higher than recorded in cowpea (1.21), pigeon pea (1.82) (Salunkhe and Kadam 1989). milletogi (1.62) (Oyarekua and Eleyinmi, 2004).

Table 6. Effect of sprouting using saline water (NaCl2000ppm) on Nutritional quality of one dey Chickpea 2 day Lentil (Lent) sprout

\begin{tabular}{|c|c|c|c|c|c|c|c|c|c|c|}
\hline $\begin{array}{c}\text { amino acids (AA) } \\
\text { composition }\end{array}$ & $\begin{array}{l}\text { Whole } \\
\text { seeds }\end{array}$ & $\begin{array}{c}\text { Chick } \\
\mathrm{TW}^{(1)}- \\
\mathrm{ST}^{(2)}\end{array}$ & $\begin{array}{l}\text { Chick } \\
\text { TW - } \\
\text { NST }^{(3)}\end{array}$ & $\begin{array}{c}\text { Chick } \\
\text { SW }^{(4)}- \\
\text { ST } \\
\end{array}$ & $\begin{array}{l}\text { Chick } \\
\text { SW - } \\
\text { NST }\end{array}$ & $\begin{array}{l}\text { Whole } \\
\text { seeds }\end{array}$ & $\begin{array}{c}\text { Lent } \\
\mathrm{TW}^{(1)}- \\
\mathrm{ST}^{(2)} \\
\end{array}$ & $\begin{array}{c}\text { Lent } \\
\mathrm{TW}- \\
\mathrm{NST}^{(3)}\end{array}$ & $\begin{array}{c}\text { Lent - } \\
\text { SW }^{(4)}- \\
\text { ST }\end{array}$ & $\begin{array}{l}\text { Lent- } \\
\text { SW - } \\
\text { NST }\end{array}$ \\
\hline $\begin{array}{l}\text { TEAA+HiST+ARG } \\
/ \text { TAA\% }\end{array}$ & 51.76 & 49.87 & 46.70 & 46.70 & 48.63 & 47.16 & 58.34 & 48.94 & 49.92 & 49.54 \\
\hline TEAA /TAA \% & 39.75 & 37.82 & 36.68 & 36.33 & 37.17 & 35.12 & 38.19 & 37.46 & 38.08 & 37.88 \\
\hline TNEAA / TAA \% & 60.25 & 62.17 & 63.31 & 63.66 & 62.82 & 64.87 & 61.80 & 62.53 & 61.91 & 62.11 \\
\hline TSAA(METH+CYS) & 4.47 & 3.17 & 2.7 & 2.51 & 5.08 & 2.14 & 1.91 & 2.91 & 2.29 & 2.44 \\
\hline ARAA(PHEN+TYR) & 9.12 & 8.48 & 8.01 & 7.6 & 8.38 & 8.29 & 7.71 & 7.8 & 8.5 & 7.72 \\
\hline TEAA / TNEAA & 65.95 & 60.84 & 57.91 & 57.07 & 59.17 & 54.13 & 61.78 & 59.92 & 61.50 & 60.98 \\
\hline CYS / TSAA \% & 53.69 & 51.41 & 53.33 & 51.79 & 65.74 & 53.73 & 50.78 & 69.07 & 56.33 & 66.80 \\
\hline TAAA (ASP+GiUT) & 27.7 & 26.81 & 24.4 & 23.86 & 26.47 & 28.6 & 25.00 & 26.03 & 28.66 & 24.3 \\
\hline TBAA(ARG + LYS) & 15.83 & 14.55 & 12.07 & 13.2 & 14.14 & 15.47 & 13.73 & 14.25 & 16.04 & 31.41 \\
\hline LEU / ISOIE & 1.79 & 1.79 & 1.82 & 1.84 & 1.76 & 1.84 & 1.75 & 1.76 & 1.75 & 1.74 \\
\hline PER & 2.32 & 2.09 & 2.99 & 2.8 & 2.02 & 2.24 & 1.51 & 1.96 & 2.26 & 1.81 \\
\hline EAA \% & 97.75 & 84.24 & 77.32 & 75.33 & 84.19 & 71.38 & 77.03 & 77.59 & 86.64 & 74.02 \\
\hline BV \% & 94.85 & 80.12 & 72.57 & 70.40 & 80.07 & 66.10 & 72.27 & 72.87 & 82.74 & 68.98 \\
\hline Natritiomlindex & 17.89 & 19.04 & 17.17 & 16.72 & 18.86 & 17.99 & 23.65 & 19.63 & 21.49 & 23.54 \\
\hline
\end{tabular}

(1)TW=tap water (2)ST=sterilized seeds (3)NST=non-sterilized seeds (4)SW=saline water

Chickpea sprouts in both tap water and saline water decreased essential amino acid index (EAAI) to $75.3-84.2 \%$ compared with whole dry seeds $(97.7 \%)$ while opposite results was obtained with lentil sprouts which increased EAAI (74-86.6\%) than whole Lentil seeds (71.4\%) (Table 6). However, EAAI of Chickpea seeds flour had the highest value than Lentil seeds flour. Moreover the EAAI of both Chickpea and Lentil seeds and their sprouts were useful for food. Since their values are higher than $70 \%$ and around $80 \%$ (Oser, 1959) while, Chickpea seeds flour showed good nutritional quality since the EAAI is above $90 \%$ as reported by Oser (1959). These vesults show that consumption of wheat flour alone in bakery food are in adequate (EAAI less than $70 \%$ as reported by $\mathbf{~ l b}$ rahim (2017) without complement with other protein - based flours (as Chickpea and Lentil seeds and sprouts in these results which recorded $74 \%$ to $97 \%$ EAAI (Table 6)), to meet the nutritional needs of consumers for bakery products. It is well known that a protein - based food nutritional is of good nutritional quality when it is biological values (BV) is high (70\% to $100 \%)$ (Oser, 1959). BV ex- 
hibited the highest percentage in Chickpea seeds $(94.8 \%)$ and their sprouts flour (between $70.4 \%$ to $80.1 \%)$ than Lentil seeds (66.1\%) and their sprouts (between $69 \%$ to $82.7 \%$ ). BV obtained from Lentil seeds $(66.1 \%)$ and non-sterilized Lentil seed sprouting in saline water (69\%) was in agreement with the good nutritional quality (70 to 100\%) for flour, protein (Oser, 1959). From the present study, the flour of Chickpea seeds $(B V=94.8 \%)$ and its sprouts especial sterilized seeds sprouting in tap water or non- sterilized seeds sprouting in saline water (BV-80.1\%) in addition to Lentil sterilized seeds sprouting in saline water $(B V=82.7 \%)$ is recommended for supplementation with cereals flour for bakery products to increase its protein quality. The study also observed that the BV and EAAI values were generally high in Chickpea flour and these could be attributed to the fact that Chickpea is high in protein content compared with Lentil. Similar results with Chickpea flour was obtained by Ibrahim (2017). Concerning nutritional index (NI), data in Table 6 showed that Chickpea and Lentil dry seeds in addition to Chickpea sterilized seed sprouts in salin water and non- sterilized sprouts in tap water flour recorded the lowest nutritional index $\mathrm{NI}$ (less -than 18\%). In contrast, the highest $\mathrm{NI}$ was obtained in Lentil sprouts using tap water (19.6 to $23.6 \%)$ and using saline water (21.5 to $23.5 \%$ ) followed by Chickpea sterilized seed sprouts in tap water (19\%) and non- sterilized sprouts in saline water (18.9\%).

\section{REFERENCES}

Abdallah M.M.F. 2008. Seed sprouts, a Pharaoh's heritage to improve food quality. Arab Univ. J. Agric. Sci., 16(2), 469-478.

Alajaji S.A. and El-Adawy T.A. 2006. Nutritional composition of chickpea (Cicerarietinum L.) as affected by microwave cooking and other traditional cooking methods. J. Food Comp. Anal., 19, 806-812.

Alonso R., Aguirre A. and Harzo F. 2000. Effects of extraction and traditional processing methods on antinutrients and in vitro digestibility of protein and starch in faba and kidney beans. Food Chem., 68, 159-165.

Alozie Y.E., Iyam M.A., Lawal Q., Udofia U. and Ani I.F. 2009. Utilization of Bambara ground flour blends in bread production. J. Food Technol. 7(4), 111-114.

Alsmeyer R.H., Cunningham A.E. and Happich M.L. 1974. Equations predict PER from. amino acid analysis. Food Technology 7(28), 34-42.
Aly, Tahany, A.A., El-Rahim E.A., Fayed S.A., Amal M.A. and Abdallah M.M.F. 2018. Influence of sprouting on chemical composition and protein quality of radish (Raphanus sativus) and clover (Trifolum alexandrinum) seeds. J. Biol. Chem. Environ. Sci., 13(1), 339-355.

AOAC. 2012. Official Methods of Analysis of AOAC International. $19^{\text {th }}$ ed. methods .No. 968.06. Chapter 4.pp. 25-26, No.994. 12 chapter 4, pp. 9-13 and No 968.08 chapter 4, 56 p.

Ashraf M. 1994. Breeding for salinity tolerance in plants. Critical Rev. Plant Sci. 13(1), 17-42.

Cappuccio F.P. and McGregor G.A. 1991. Does potassium supplementation lower blood pressure ? A meta- analysis of published trials. J. Hypertens, 9, 465-473.

Cheryan M. 1980. Phytic acid interactions in food systems. CRC Critical Rev. Food Sci. Nutr. 13, 296-335.

Chinma C.E. and Igyor M.A. 2007. Micronutrients and anti-nutritional contents of selected tropical vegetables grown in South Fast. Nigeria. Nig. Food J. 25,111-116.

Day R.A. and Underwood A.L. 1986. Quantitative Analysis ( $5^{\text {th }}$ ed.) Pnentice - Hall publication $701 \mathrm{p}$.

Despande S.S. 1992. Food legumes in human nutrition : a personal perspective. Rev. Food Sci. Nutr., 32, 333-363.

Eneche E.H. 1991. Biscuit- making potential of millet/ pigeon pea flour blends. Plants Foods Human Nutr., 54, 21-27.

FAO/WHO/UNU 1985. Energy and protein requirements. WHO Technical Report Series No. 724. Geneva: WHO.

Farzana W. and Khalil A. 1999. Protein quality of tropical food legumes. J. Sci. Technol., 23, 1319.

Fasasi O.S. 2009. Proximate antinutritional factors and functional properties of processed pearl millet $(P$. ennisetumglaucum). J. Food Technol., 7(3), 92-97.

Ghoulam C. and Fares K. 2001. Effect of salinity on seed germination and early seedling growth of sugar beat (Beta vulgaris L.). Seed Sci. Technol., 29, 357-364.

Giannakoula A.E., Ilias F.I., Dragisic Maksimovic J., Maksimovic V.M. and Zivanovic B.D., 2012. The effects of plant growth regulators on growth, yield and phenolic profile of lentil plants. J. Food Comp. Anal., 28, 46-53.

Ibrahim S.S., Habiba R.A., Shatta A.A. and Embaby H.E. 2002. Effect of Soaking, germination. Cooking and Fermentation on antinutri- 
Sprouting using saline water on chemical composition, antinutritional compounds and amino acid profile of chickpea and lentil seeds

tional factors in Cowpeas. Nahrung / Food. 46, 92-95.

Ibrahim E.M.R. 2017. Effect of sprouting using saline water on characters and chemical composition of some legumes and cereals seeds. Ph.D. Thesis, Fac. Agric. Ain Shams Univ. Cairo. Egypt. pp. 32-80.

ljarorimi, S.O. and Keshinro, O.O. 2013. Determination of nutrient composition and protein quality of potential complementary foods formulated from the combination of fermented popcorn, African locust and Bambara groundnut seed flour. Polish J. Food. Nutr. Sci., 63(3), 155-166.

lqbal A., Khalil I.A., Ateeg N. and Khan M.S. 2006. Nutritional quality of important food legumes. Food Chem., 97, 331-335.

Jukantial A.K., Gaur P.M., Gowda C.L.L. and Chibbar R.N. 2012. Nutritional quality and health benefits of chickpea (Cicrarietinum L.). A., review. Br. J. Natr. 108, 511-526.

Kalpanadevi V. and Mohan V.R. 2013. Effect of process. Ing on antinutrients and in vitto protein digesibility of the under at ilizedlegume, vignaunguiculata (L.) walpsubso. unguiculata. Food Sci. Technol., 51, 455-461.

Khattak A.B., A. Zeb, M. Khan, N. Bibi, Ihsanullah and Khattak, M.S. 2007. influence of germination technique on sprout yield biosynthesis of ascorbic acid and cooking ability in chickpea (Cicerarietinum L). Food Chem., 103, 115-120.

Khan M.I.R., Mughal A., Iqpal N. and Khan A., 2013. Potentiality of sulphur containing compounds in salt stress tolerance. In Ecophysiolgy and responses of plants under salt stress. Eds., Parvaiz, A.M.M. Azooz and M.N.V. Prasad, springer, pp. 443-473.

Kumar V., Sinha A.K., Makkar H.P.S. and Becker K. 2010. Dietary roles of phytate and phytase in human nutrition. A Rev. Food. Chem. 120, 945-959.

Labuda, J., Kacerovsky, O., Kovae, M. and Stìrba, A. 1982. Vyziva a krmenie hospodarskych zvierat. Príroda, Bratislava. 164s p.

Langford H.G. 1983. Dietary potassium and hypertension: epidemiologic data. Ann. Lnt. Med. 98(2), 770-772.

Liener I.E. 1994. Implications of antinutritional components in soybean foods. Crit Rev. Food Sci. Nutr., 34, 31-67.

Mahmoud A.H. and El-Anany A.M. 2014. Nutritional and sensory evaluation of a complementary food formulated from rice, faba beans, sweet potato flour, and peanut oil. Food Nutr. Bull. 35(4), 403-413.
Makkar H.P.S., Blu Smmel M., Borowy N.K. and Becker K. 1993. Tannic acid was used as a standard material. Gravimetric determination of tannins and their correlations with chemical and protein precipitation methods. J. Sci. Food. Agric. 61, 161-165.

Mbithi-Mwikya S., Van Camp J., Rodri Guaz R. and Huyghebaert A. 2001. Effects of sprouting on nutrient and antinutrient composition of kidney beans. Eur. Food Res. Technol., 212, 188-191.

Moongngarm A. and Saetung N. 2010. Comparison of chemical composition and bioactive compounds of germinated rough rice and brown rice. Food Chem. 122, 782-788.

Mune-Mune M.A., Minka S.R., Mbome LL. and Etoba F.X. 2011. Nutrition potential of Bambara been protein concentrate. Pakistan J. of Nutrition 10(2), 112-119.

Nieman D.C., Buterworth D.E. and Nieman C.N. 1992. Nutrition. WmC.Brown, Dbugye, USA. pp. 237-312.

Nwabueze T.U. 2007. Nitrogen solubility index and amino acid profile of extruded African bread fruit (T. Africana) blends. Nig. Food. J. 25, 3535.

Onwuka G.I. 2006. Soaking, boiling and antnutritional factors in Pigeon Pea (Cajanuscajan) and Cowpea (Vignaunguiculata). J. Food Proc. Preser., 30, 616-630.

Osborne D.R. and Voogt P. 1978. The analysis of nutrients in foods. Academic Press, London, UK.

Oser B.L. 1959. An integrated essential amino acid index for predicting the biological value of proteins. Ln protein and amino acid nutrition. (ed. A.A. Albanese). Academic Press, New York, USA, pp. 295-311.

Oyenuga, V.A. 1968. Nigeria foods and feeding stuffs: their chemistry and nutritive value. Ibadan: University Press. Temple VJ, Badamosi EJ, Ladeji O, Solomon M. (1996). Proximate chemical composition of three locally formulated complementary foods. West Afr. J. Biol. Sci., 5, 134-143.

Oyarekua M.A. and Eleyinmi A.F. 2004. Comparative evaluation of the nutritional quality of corn, sorghum and millet ogi prepared by modified traditional technique. Food Agric. Environ., 2, 94-99.

Paul A.A. and Southgate D.A.T. 1976. McCance and Widdowson's. The Composition of Food $\left(4^{\text {th }}\right.$ ed.) London, HMSO.

Raddy N.R. and Salunkhe D.K. 1981. Lnteractions between phytate, protein and minerals in whey fractions of black qram. J. Food Sci., 46, 564-570. 
Rady M.M. 2011. Effect of 24-epibrassinoillde on growth, yield. Antioxidant system and cadmium content of bean (Phaseolus vulgaris L.). Plant under Salinity and cadmium stress. Scientia Horticulturae, 129, 232-237.

Salunkhe D.K. and Kadam S.S. 1989. Handbook of world food legumes, nutritional chemistry processing technology and utilization. Florida, USA; Boca Raton, CRC Press.

Sandberg A.S. 2002. Bioavailibility of minerals in legumes. Br. J. Nutr., 88(3), S281-S285.

Semida W.M. and Rady M.M. 2014. Presoaking application of propolisand maize grain extracts alleviates salinity stress common bean (Phasseolus vulganis L.) Science Horticulture, 168, 201-217.

Shalaby Rasha A., Serage Afaf O., Abdel-Chany Zeinab, M. and Mohamed Noha M. 2017. Study of using some Legumes for household meat substitute "Luncheon". J. Food Dairy Sci. Mansoura Univ., 8(5), 217-223.

Shehata A.M.E.L. 1992. Hard. To. Cook phenomenon in legumes. Food Rev. Int., 8, 191-221.

Snedecor G.W. and Cochran W.G. 1980. Statistical methods $7^{\text {th }}$ ed., lowa State Univ. Press , Ames lowa, USA.

Soetan K.O. 2008. Phar. Macological and other beneficial effects of antinutritional factors in plants. A Review. Afr. J. Biotechnol., 7(25), 4713-4721.

Wheeler E.L. and Ferrel R.E. 1971. A method for phytic acid determination in wheat and wheat fractions. Cereal Chem. 48, 312-320.

Yildirim E., Dursun A., Gurenc I. and Kumlay, A. 2002. The effects of different Salt, bio stimulant and temperature levels on seed germination of Some vegetable species. Acta Agrobotanica. $55,75-80$. 
مجلة اتحاد الجامعات العربية للعلوم الزراعية ، جامعة عين شمس ، القاهرة ، مصر

مجلد(26)، عدد(2D)، عدد خاص ، 2251-2239، الجرات ، 2019

Website: http://strategy-plan.asu.edu.eg/AUJASCl/

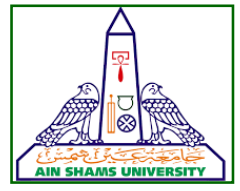

2251

تأثير التنبيت بإستخدام الماء المملح على المكونات الكيميائية ومضادات التغذية والأحماض الأمنيية فى بذور الحمص والعدس الكي

[162]

محمد عبد السلام عبد العظيم 1 - نشوة عطية ابراهيم ابوالعزم2 - عفاف عمر سراج الدين 1 -

ممدوح محمد فوزى عبد الله 2

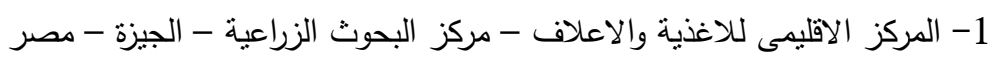

2- قسم البساتين - كلية الزراعة - جامعة عين شمس - ص.ب. 68 - حدائق شبرا 1142 - القاهرة - مصر

*Corresponding author: youmamdouh@yahoo.com

Received 24 April, 2018

Accepted 5 June, 2018

محتوى البروتين والطاقة مقارنة بالمعاملات الاخرى او

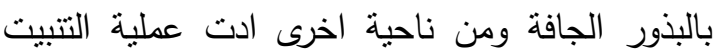

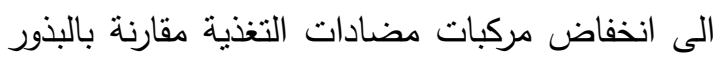

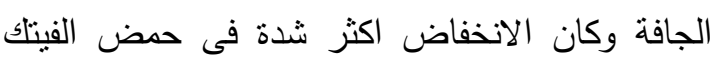

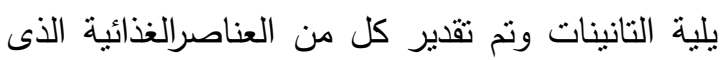

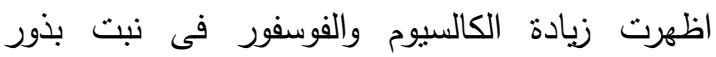

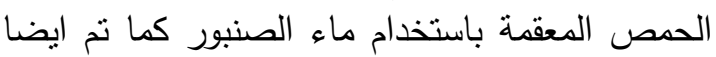

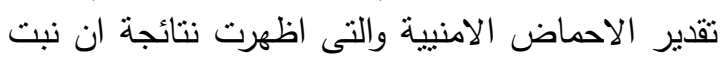

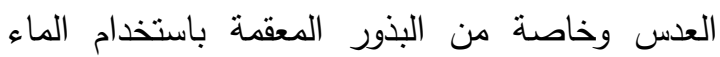

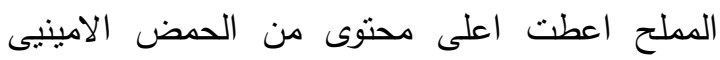

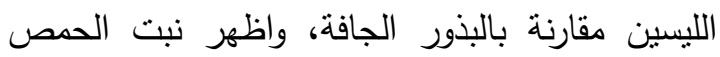
الناتج من البذور غبر المعقمة باستخدام الماء المثلح

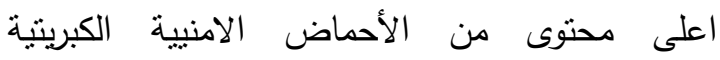

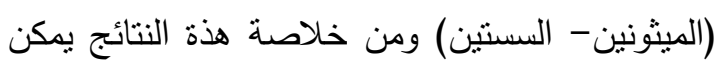
التوصية باجراء عملية التتبيت لرفع القينة لفيمة الغذائية وتقليل مركبات مضادات التغذية لكل من بذور الحمص لتصف والعدس.

الكلمات الدالة: الملوحة، حمص، عدس، عملية التتبيت، تحليل المكونات، الاحماض الاضنية

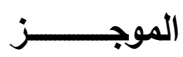

استخدمت بذور الحمص والعدس لدراسة تاثير

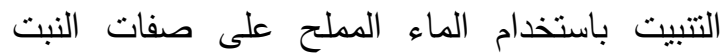
وتحليل المكونات والطاقة والعناصر الغذائية ومضادات الغات الغات

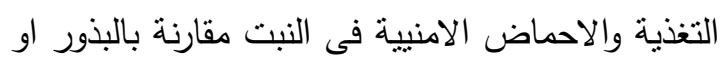

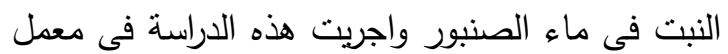

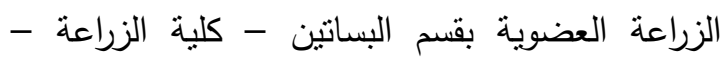
جامعة عبن شمس والتحليلات الكيمائية تم تقديرها بالمركز الاقليمى للاغذية والاعلاف واظهرت البهن نتائج

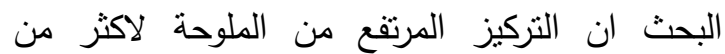

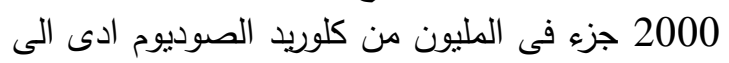

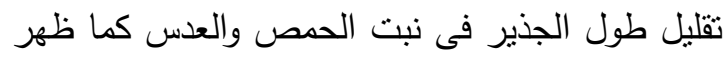
انخفاض محتوى النبت من الرطوبة والكربوهيدرات

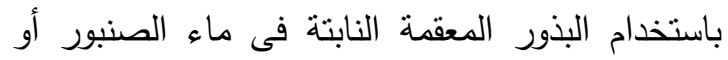

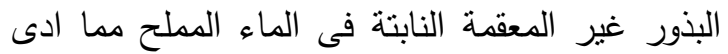

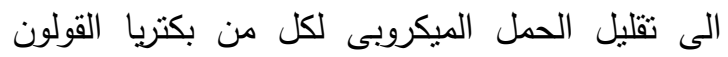

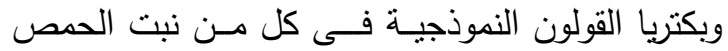

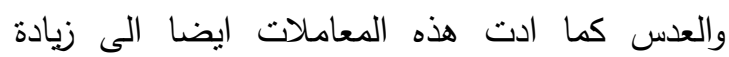



